\title{
THE WAIT ON QUEZON AVENUE
}

\section{Robert Nery}

neryrobert@hotmail.com

\section{About the Author}

Robert Nery grew up in Cagayan de Oro. He has made two non-fiction films, Black Nazarene and In 1966 The Beatles Came to Manila. His book of translations, Poems of Rolando S. Tinio, Jose F. Lacaba and Rio Alma, was published by Vagabond Press in 2014. 
An image projected on that dark night, left by the vanishing soul: a pagoda, undulating: stacked billiard tables, the balls colliding, ricocheting, each table standing on another, except for the last - the pagoda is finite - the last table less a solidity than a flicker of energy. Where does consciousness fit in? Is it a property of the clusterings and collisions of the billiard balls, or of the balls themselves, or of the tables that come with the balls? Consciousness, that which nervous systems have when awake, which is, more exactly, their being awake to a world. Its basic form: having-sensations. From this wonderland of colors and sweet and sour and twinges of pain, computers and robots so far are excluded, though they may register changes in light frequency or simulate animal responses to injury or be designed to chemically distinguish a steak from a crème brûlée. What excludes them, we don't know. Descartes held the view that animals other than humans were not conscious, were robots more or less complex, a view some of us may find not only implausible but morally repugnant. Still, even when we profess to believe that our nervous systems are nothing more than matter, we, inheritors of both the divide between spirit and flesh and that between matter and mind, think of our material constitution as a letdown, a reduction to something simpler, stupider, than we thought. To say that we are wholly materially constituted is only to say that what we are constituted by is subject to the laws uncovered by physics. Yet, powerful and comprehensive, our physics lacks the slightest understanding of how matter can be conscious. What happens to give us sensations? And what is going on when our neurons fire in the dark, and we dream? Even without the problem of consciousness, matter is mysterious. Physical explanation resigns itself to certain constants, certain recurrences being given and inexplicable, the facts on which all other facts depend. They are decided by a god, we could say, but to say this is to replace one mystery with another. Why should it be more satisfying to embrace the mystery of God than to clasp the mystery of Nature to our breasts? TThere is consolation in Spinoza's claim that there exists only one thing, God-orNature. (Though we may have to consider that there are universes...form a mutually dependent system.) We are not separate entities from God-or-Nature, as human beings or persons.Each one of us is - to renovate Spinoza-a system of properties of shifting location in space-time, like a jellyfish entirely made of the elements that make up the water in which it swims. Spinoza also thought that mentality was an aspect of the One Thing. To renovate him again, the being-consciousness of the region in space-time I am, is constituted from a property of what makes up space-time. Consciousness, therefore, is less like the processing speed or memory capacity of a computer than it is like electricity. To Spinoza, the independently existing self is an illusion, for there is only the One Thing; there cannot therefore be an unchanging substance like a soul. If the soul exists, it constitutes the self, and I survive my body if my soul does. But the theory of the soul is a strange, hybrid, impossible beast. No, we have only bodies, in their mystery, and their activity, which includes being conscious. That something immaterial, independent of the 
body, is the bearer of consciousness-as folklore has it-is shown to be false by the fact that certain kinds of damage to the human brain cause certain forms of agnosia, strange defects in one's consciousness of the world. The window casts a narrow rectangle of light on the floor every afternoon this summer, in the room where I sit, where I have sat on and off for many days. These castings of light happen whenever it is sunny; they are predictable. The angle of these projectings will change predictably, over the season. Between days the change in angle is almost imperceptible, and the area of light today is not much different from yesterday's. Is the image I see today one and the same thing as the image I saw yesterday? The raintree opposite our house in Mambajao when I was six years old, scattering its coppers on the sand and coral of the street, is the same thing as the one I saw in 1995 in front of the rundown bungalow, after more than thirty years. If the tree I saw when I was six had never existed, there would be no tree to see in 1995 . Whereas, if yesterday's bright oblong had not existed (if it had been dark and rainy yesterday), today's bright oblong might yet exist. Whether this image today and yesterday's are to be counted one and the same is a matter of convenience. It was here yesterday, too, I might say. Or it's another image, I might say, but very like the one yesterday. And this bright clearing, this illumination, and the $I$ in it, the $I$ to which the world is present, visibly, audibly? I was yesterday - at this time of the night waiting at the bus stop rather than writing; that was me, one and the same $I$. So I can't help thinking. The sky shuts down, night falls on the nervous system, neither dreaming nor awake, and the world ceases to be present. Do I cease to be? If I persist, where am I? In the body? The Advaita Vedantists believe there is only one atman or self, the Atman: Whoever says " $\mathrm{I}$ " is the only self there is, and has acquired the habit of thinking itself Robert Nery, the emperor Constantine, or Imelda Marcos. The only Self is manifest wherever there is sentience, in dogs and ants as well as human beings. We are thus terminals of the one mind, as of a computer, each terminal with its self-regarding history. I think of myself as Robert Nery. The I-it may be-has the tendency, a rather endearing one, of mistaking itself for you and me. But I have no conviction in a soul that may outlive the body, nor in the Atman and its immortality. If, according to the Vedanta, Rizal, standing in the seaside park, his back to the firing squad, recognized in that moment of suspense that his existence as a self was an illusion, that he was merely a mask of the one Self, and the crowd was a collection of masks, that the dead-eyed natives of the firing squad he, falling, pivoted to face are masks, then he would have realized he could not die, because the only Self does not die. If there is no real self at all, nothing persisting, and Rizal at that moment before he fell recognized that his identity was an illusion, then he would have realized that he could never die, because he, Jose Rizal, had always been a myth. For a time, a ferry took visitors directly from Cagayan de Oro to Camiguin island, rounding the steep honeycombed slope along its southeast part, with grottoes and tiny coves overhung with coconuts, to land in Binoni, the metal roofs of its brown stilt houses glinting in the distance like mica in a broken 
stone turned in one's hand in the sunlight. The sea between the island and the curve of the bay, the sea behind the island, is given to unearthly calm in sunny weather. The water is darker and often sleek, which one noticed when one drove around the island from Mambajao. Once as the ferry retraced its route in the afternoon, coasting the bristly-palmed hills of the mainland, the weather was fine and the sea unbroken by a single scudding wave. The white island clouds adrift in the pale blue open space above were admiring themselves in the calm, which the old converted tugboat interrupted, whose wake rippled into dark water. The tugboat chugged, small, unhurried, on a mirror, this coincidence of cloud and weather and sea and crescent of land. Conscious experience is a coincidence, a sublime coincidence; I am as long as it occurs, and cease when it comes to an end. It has no autobiography, and this one you are reading is a text taken up and continued over several days by fugitive selves.

Robert Nery keeps on returning to the Philippines, the country in which he hasn't lived for a long time. A violet darkness, rising from the earth, submerges the megacity, and disperses like smoke in the sky, the softly lit veined inside of an eyelid. I get off at the train station on the corner of EDSA and Quezon Avenue. He has found himself here before, on this intersection, on his visits to the Philippines. Ponderous Egyptian pillars support the station platform four stories above the highway, similarly massive train stations looming at regular intervals along EDSA, on the swarming plain of Greater Manila. He walks down the wide steps of the stairs, and before the wide landing ragged children are sitting on the steps, putting out hands absent-mindedly for change, the middle of the polished concrete floor below filmed by a shrinking circle of water, under the orange dusk of the stairway lights. Earlier today, in the steamy afternoon, children, the same perhaps, were skidding on the floor's limpid surface. Now, although their high-pitched voices still defy the night, one girl maybe ten years old and younger boys and girls, in dirty fraying clothes, are huddled on the stairs, the kids maybe of the vendors at the foot of the stairs, who are selling cigarettes, mints, garlic peanuts, peeled green mangoes with small plastic bags of shrimp paste or sea-salt, small toys. The oldest girl hugs a two-year boy in an oversized T-shirt. So much unrecompensed goodwill. I step out. My face proclaims its uniqueness among the thousands of other faces that proclaim theirs. But it is night, and when I walk out along the highway, these faces are only intermittently distinguishable. Before going down the stairs, on the high concrete walkway across the tracks, I stopped and looked down to the darkness of a large field far below along the six lanes of EDSA, a wasteland of cogon beside it and beyond. The lights of the motor vehicles heading towards me making it harder to see into the field, there-at the far end, on the edge of a series of ovals of green in the dark, a green faintly aglow like the luminous hands of an old watch-were mansized upright placards, tiny in the distance, drifting, forward, sideways, backward, forward. Some of the placards, so faintly lit, blurred when looked at directly, like 
remote stars. What was happening down there? Occasionally, when allowed by the traffic, came a tiny thwack, then the roar of traffic, another thwack. Yes, it is a driving range. I need to get a taxi, or a jeepney, along Quezon. Alone on the street in Manila, I am never off guard. The possibility of being mugged, or when I am already in a taxi, taken somewhere and robbed, is always in the back of my mind, and at night I feel the threat of the megacity's anarchy in my chest. To be out with friends and acquaintances, amidst their indulgent humoring intimacy, is to be granted a halo of protection, the circle of a tribe or section of a tribe. Together we can part the Red Sea. A line of people walk away towards Quezon Ave and another line of people walk towards the station, the two lines on a meter-wide muddy footpath between EDSA and the chain-mail fence of a parking lot for jeepneys, a muddy clearing in the cogon of the public land along the highway. The night, after the cold of the train, is an immersion in blood. Entering through a tear in the fence, I cross a catwalk over a ditch to the lot's muddy tire tracks, take a seat in the first jeepney on the queue, parked next to a wooden metal-roofed shed, and wait until no space in the jeepney is unoccupied. It is the last leg of my journey. A few days ago, near the station steps, on the highway, wafting above and sinking in traffic, a blind man was singing a harshly amplified lament. Despite my feeling safer, in my chest is something like grief: alone amidst the thousands of human lives that crowd Manila, or in their desertion of the streets late at night, I am aware that my self-concern is no one else's. Robert Nery cannot mean what hemeans to me to any one of these hundred thousands that are present to me through the day or have left me by myself, each one a center of conscious life, of a perspective on the world, of the wakeful here-and-now. Yet-this point of view that is mine, that, in a sense, I am-could have other memories than his, other desires, yet still be mine; it could be other than Robert Nery's. Perhaps one day I shall wake up someone else, having forgotten being anyone previously. To be Robert Nery is to be the hero of a story. (The Christian saint sought to bring an end to his or hers, not in death itself but in the union of his or her will with God's. Hell, in Dante's Inferno, is a continuation of our world in the following respect: its denizens remember the events that occur to them. If the suffering of pain were perfectly unself-conscious, there would be no-one, in a sense, to suffer it; the damned must therefore be conscious of themselves as persisting. Things happen to them. Nothing happens to the blessed, however, absorbed as they are in timeless being. The visions granted to Dante in the Paradiso, which the blessed conjure for his sake, lack dramatic interest in principle.) Yet the crowds of Manila, where every face declares its uniqueness, have the effect of deflating the value of one's originality. Some years ago, there was no jeepney terminal. During that visit to Manila I was coming back a few nights every week from work in the provinces north of the city and getting off the bus at the corner diagonally across the intersection from today's jeepney terminal, and from the corner my friend and I would scuttle with our bags across Quezon Avenue, when the river of buses and jeepneys had incredibly paused, stopping over at 
the policeman's hut on the avenue's desert island. There were buses then along Quezon, and we would walk down: under the sparse fluorescent streetlights, an enormous crowd stretched out along the avenue, as if on one side of Lethe in flood, waiting to be ferried somewhere downstream, consoled by the blare of a karaoke bar, the life to be left behind. The java plum was in season. On the corner where we got off the bus were street vendors sitting on stools, one behind a flat basket of the piled blue-black cherry-sized plums, another behind a pile of garlic peanuts. A bag of plums came with a plastic sachet of sea-salt. I ate them as we walked up and down checking out the place-name plaques awry on the windshields of buses. Dark as the night, a darkness sprinkled with salt, the plums stain the mouth violet and leave an aftertaste of mint and iodine.

\section{Note}

On subjectivity, I have learned much from "What is the Relation Between an Experience, the Subject of the Experience, and the Content of the Experience?" in Strawson, Galen, Real Materialism (Oxford: Clarendon Press, 2008). I have learned even more from Mark Johnston's Surviving Death (Princeton: Princeton University Press, 2011). 
